\title{
Aktivitas Public Relations Bank BJB Dalam Menerapkan Budaya Perusahaan
}

\author{
Femi Oktaviani \\ Universitas ARS \\ feoktav@ars.ac.id
}

\begin{abstract}
Public relations (PR) has an essential role in a company, as in the banking world is needed in facing banking competition that is so competitive. Corporate culture in a company is directed to support the strategy and long-term business development to have higher endurance and competitiveness. Public relations are necessary for implementing corporate culture because culture is the foundation in managing a company and supporting a company to achieve optimal performance. This study aims to determine the form of PR commitment and PR activities in implementing corporate culture. This research is qualitative research using a case study approach. The results obtained are a form of commitment consisting of affective commitment by the go spirit and commitment to building teamwork. Then normative commitment consists of an agent of trust (professionalism, respect, integrity, trust, and agent of development), which is implemented through cultural values of innovation and agent of service. The challenges faced by PR in implementing corporate culture are personal culture, customers or partners' challenges, and inter-division team building that has different roles and functions.
\end{abstract}

Keywords: Public Relations, Corporate, Culture.

\section{Pendahuluan}

Public relations (PR) merupakan suatu bagian yang tidak bisa lepas dari suatu perusahaan. Secara umum, PR menjalankan kegiatan manajemen yang dapat membangun dan memelihara komunikasi baik internal maupun eksternal, membangun kerja sama antar berbagai stakeholder, serta bertanggung jawab terhadap citra perusahaan, sehingga tak heran jika PR menjadi ujung tombak keberhasilan dari suatu perusahaan.

Menurut penelitian terdahulu tentang peran budaya organisasi dalam membangun hubungan antar karyawan, faktor komitmen terhadap organisasi berdampak pada pengembangan dan SDM dari organisasi itu sendiri. Selain itu, budaya organisasi berperan dalam mengukur keberhasilan organisasi, dengan adanya temuan penelitian terdahulu ini, maka peran PR dalam menerapkan budaya perusahaan di suatu organisasi sangatlah penting.(Petra, 2014)

Peran PR yang paling penting adalah sebagai fasilitator komunikasi, di mana PR dapat bertindak sebagai komunikator atau mediator yang dapat membantu manajemen untuk mendengar harapan yang diinginkan oleh publiknya baik secara internal maupun eksternal. Di samping itu, PR berperan sebagai teknisi komunikasi yang dapat menyediakan dan memberikan layanan teknis komunikasi di dalam suatu perusahaan, agar kebijakan-kebijakan yang ada dapat diketahui oleh publik internal dan eksternal dari suatu perusahaan.

Selanjutnya, menurut penelitian terdahulu, budaya organisasi sangat berpengaruh signifikan terhadap komitmen karyawan dalam meningkatkan kinerja. Dari hasil penelitian ini, tentunya kehadiran PR dalam menerapkan budaya organisasi sangatlah diharapkan untuk menjaga eksistensi organisasi di mata publik (Prayudhayanti et al., 2005).

Praktisi PR harus dibekali dengan pengalaman-pengalaman dan kemampuan yang tinggi untuk membantu memberikan solusi dalam menghadapi krisis yang terjadi dalam 
perusahaan. Adanya pemahaman tentang peran dan fungsi PR dapat menjadi suatu acuan bagaimana perusahaan dapat dikelola dengan baik sehingga tetap eksis dan mendapat kepercayaan publik yang berdampak pada reputasi yang baik bagi perusahaan. Selain itu, untuk mendapatkan reputasi yang baik dari suatu perusahaan, peran PR juga sangat diperlukan dalam menerapkan budaya perusahaan. Hal ini karena budaya merupakan fondasi dalam pengelolaan perusahaan dan pendorong perusahaan mencapai kinerja secara optimal. Budaya perusahaan harus selaras dengan visi, misi, dan strategi perusahaan serta mampu menjawab tantangan-tantangan yang terjadi saat ini dan di masa yang akan datang.

Seperti yang dikemukakan pada penelitian terdahulu tentang aktivitas komunikasi PR, menjaga hubungan internal dan eksternalnya dinilai penting untuk mengimplementasikan budaya organisasi. Maka, dalam dunia perbankan, sebagai suatu organisasi diperlukan peran PR untuk menerapkan budaya organisasi dalam menghadapi persaingan perbankan yang begitu kompetitif yang dapat membedakan antara bank satu dengan bank yang lainnya (Oktaviani, 2020).

Budaya perusahaan tidak hanya menjadi salah satu variabel yang berhubungan dengan penentuan peningkatan kinerja perusahaan, tetapi memiliki fungsi di dalam suatu organisasi, salah satunya menciptakan perbedaan antara satu perusahaan dengan perusahaan yang lain. Dalam dunia bisnis perbankan, penerapan budaya perusahaan sangatlah penting karena dapat menjadi pembeda antara bank satu dengan bank yang lainya. Dalam meneruskan pencapaian visi perusahaan dan mengantisipasi tantangan global maupun lokal, maka, diperlukan PR yang handal yang memiliki daya tahan dan daya saing yang berkualitas.

Pengembangan budaya perusahaan adalah salah satu aspek penting dalam membangun fondasi yang lebih kuat. Kegiatan pengembangan budaya perusahaan diarahkan untuk mendukung strategi dan pengembangan bisnis jangka panjang sehingga perusahaan memiliki daya tahan dan daya saing yang lebih tinggi. Di samping itu, budaya perusahaan merupakan fondasi penting bagi perusahaan dalam mendukung pencapaian visi dan misi perusahaan agar berkinerja baik dan mendapat kepercayaan publik.

Bank BJB merupakan salah satu bank terbesar di Jawa Barat dan memiliki reputasi yang baik di Indonesia. Transformasi budaya perusahaan bank BJB mengalami perubahan dari waktu ke waktu. Hal ini terjadi sebagai bentuk upaya dalam pencapaian visi dan misi bank BJB. BJB merupakan salah satu Badan Usaha Milik Daerah (BUMD) yang mengandalkan peran PR dalam menerapkan budaya perusahaan. Di mana budaya perusahaan tersebut mencerminkan semangat bank BJB dalam menghadapi persaingan perbankan yang semakin ketat dan dinamis. Nilai-nilai budaya perusahaan (corporate values) yang telah dirumuskan dan diterapkan, yaitu, "GO SPIRIT" yang merupakan perwujudan dari Service excellence, Profesionalism, Integrity, Respect, Innovation, dan Trust.

Internalisasi budaya perusahaan yang dilakukan oleh bank BJB berada di bawah divisi Human Capital yang dibantu oleh tim internalisasi budaya beserta pimpinan lainnya yang ditunjuk oleh setiap unit bagian yang berfungsi sebagai pelaksana proses internalisasi budaya perusahaan yang diterapkan di masing-masing unit bagian. Adanya perubahan budaya perusahaan di bank BJB bukanlah suatu hal yang mudah karena diperlukan komitmen yang kuat dari seluruh bagian bank BJB, terutama para pimpinan (top management) yang diharapkan dapat mencapai visi dan misi dari transformasi budaya perusahaan.

Budaya organisasi bank BJB ini dibangun dengan visi "GO SPIRIT". "GO SPIRIT" dijabarkan dalam 12 perilaku utama yaitu: (1) fokus pada nasabah; (2) proaktif dan cepat 
tanggap dalam memberikan layanan bernilai tambah; (3) bekerja efektif, efisien; dan bertanggung jawab; (4) meningkatkan kompetensi untuk menghasilkan kinerja terbaik; (5) jujur, disiplin, dan konsisten; (6) memahami dan melaksanakan ketentuan yang berlaku; (7) menghormati dan menghargai serta terbuka terhadap perbedaan; (8) memberi dan menerima pendapat yang positif dan konstruktif; (9) kreatif dan inovatif untuk memberikan solusi terbaik; (10) melakukan perbaikan berkelanjutan; (11) berperilaku positif dan dapat dipercaya; serta (12) membangun sinergi untuk mencapai tujuan perusahaan.

Arti semangat, jiwa, dan antusias dari "GO SPIRIT" memberikan arti bahwa nilainilai perusahaan harus mendorong karyawan untuk memiliki semangat, menjiwai, dan antusias dalam memaknai, mengamalkan, dan mengimplementasikan nilai-nilai budaya perusahaan bank BJB dalam menjalankan setiap aktivitas. Secara keseluruhan dapat diartikan sebagai nilai yang menjadi budaya karyawan bank BJB untuk bersama-sama, bekerja sama, saling membantu dalam mencapai visi, misi, dan tujuan perusahaan dengan penuh semangat serta antusias dalam memaknai, mengamalkan, dan menerapkan nilainilai budaya perusahaan serta perilaku "GO SPIRIT".

Dengan adanya budaya perusahaan tersebut, karyawan bank BJB dapat aktif berpartisipasi dalam menerapkan budaya yang dilaksanakan karena penguatan budaya merupakan tanggung jawab seluruh insan bank BJB tanpa terkecuali dan "GO SPIRIT" pun menjadi salah satu identitas bank BJB. Begitu juga dengan kinerja yang dicapai oleh praktisi PR dalam menerapkan budaya di dalam perusahaan. (Lina, 2014)

"GO SPIRIT" sebagai budaya perusahaan bank BJB sangat penting untuk karyawan agar dapat mengetahui apa yang harus dilakukan, bagaimana, dan mengapa harus melakukan suatu aktivitas, sehingga karyawan lebih yakin dalam bertindak, juga dapat meningkatkan kinerja karyawan, dan pendukung kesuksesan perusahaan dalam jangka panjang, seperti reputasi perusahaan. Fondasi budaya yang kuat merupakan langkah yang dilakukan bank BJB sebagai strategi perusahaan untuk mengontrol performa bisnis melalui implementasi nilai-nilai perusahaan.

Dalam menerapkan nilai-nilai budaya perusahaan yang ada pada bank BJB, karyawan tentunya dituntut untuk menanamkan dan menumbuhkembangkan nilai-nilai budaya perusahaan agar menjadi bagian diri mereka sendiri, sehingga karyawan mempunyai rasa memiliki. Budaya perusahaan telah hadir sebagai bagian dari sinergi yang menghasilkan perkembangan dan kemajuan perusahaan, sehingga dapat pula dijadikan alat strategis dalam menghadapi perubahan dan diharapkan sebagai salah satu pilar keunggulan kompetitif bagi perusahaan, yang kemudian akan mengantarkan perusahaan agar dapat memiliki sumber daya manusia yang mumpuni.

Kehadiran budaya perusahaan yang fleksibel menjadi semakin relevan dalam menghadapi persaingan di era globalisasi. Strategi dalam mengantisipasi perubahan yang akan dilakukan oleh suatu perusahaan juga perlu mempertimbangkan aspek budaya yang telah ada selama ini. Terutama para manajer yang berada pada tingkat teratas harus memiliki kesadaran akan pentingnya memahami budaya perusahaan karena pengaruhnya yang begitu besar terhadap perilaku karyawan, dan sering kali peran dari para manajer menjadi panutan bagi para karyawan dalam penegakkan nilai-nilai budaya perusahaan.

Perilaku perusahaan berkaitan dengan bagaimana orang bertindak dan bereaksi dalam semua jenis perusahaan. Dalam kehidupan perusahaan, SDM dipekerjakan, dididik, dilatih, diberi informasi, dilindungi, dan dikembangkan sehingga dapat memberikan kontribusi yang baik dalam mencapai tujuan perusahaan. Dalam suatu perusahaan, masalah budaya perusahaan merupakan bagian yang tak terpisahkan dengan lingkungan 
internal perusahaan, karena keragaman budaya yang ada dalam perusahaan sama banyaknya dengan jumlah individu yang ada pada perusahaan tersebut. Di samping itu, perilaku perusahaan dalam menerapkan budaya perusahaan bisa berbentuk pelayanan terhadap konsumen, penampilan karyawan, dan kemampuan berkomunikasi. (Anggraeni, n.d, 2010)

Dengan banyaknya sumber daya manusia di dalam sebuah perusahaan akan tercipta perbedaan-perbedaan sifat, watak, dan kepribadian dari setiap individu. Oleh sebab itu, budaya perusahaan sangat diperlukan dalam memberikan suatu solusi dan menjadi keyakinan, norma, dan aturan yang ada di perusahaan agar setiap individu menganut dan memahami nilai-nilai yang ada di dalamnya.

Budaya perusahaan bukanlah sesuatu yang terjadi begitu saja. Budaya perusahaan secara sengaja dibangun dan direkayasa oleh para pemimpin. Oleh karena itu, para pemimpin perlu membangun budaya perusahaan yang kuat dan kohesif sehingga dapat menjalankan usahanya menurut sejumlah prinsip dan nilai yang jelas. Nilai-nilai tersebut dikomunikasikan oleh pemimpin kepada anggota perusahaan dengan menjelaskan cara nilai dan prinsip itu berkaitan dengan lingkungan bisnis, dan memiliki nilai-nilai yang dimiliki bersama oleh para karyawan dari tingkat yang paling atas sampai bawah.

Budaya perusahaan didefinisikan sebagai seperangkat sistem nilai-nilai, keyakinankeyakinan, asumsi-asumsi, atau norma-norma yang berlaku, disepakati, dan diikuti, oleh para anggota suatu organisasi sebagai pedoman perilaku dan pemecahan masalahmasalah yang terjadi di dalam organisasinya (Sutrisno, 2010). Selain itu, budaya organisasi merupakan suatu bentuk usaha atau cara untuk memperoleh rasa, perasaan, atmosfer, karakter atau citra dari sebuah organisasi dengan menggunakan sistem nilai, keyakinan, asumsi, norma yang berlaku, dan disepakati sebagai pedoman dalam berperilaku, serta pemecahan masalah-masalah yang timbul dalam organisasi.

Budaya perusahaan sering kali tercermin dalam perilaku keseharian anggotanya, termasuk praktik sehari-hari di tempat kerja. Budaya perusahaan akan memberikan suasana psikologis bagi semua karyawan, bagaimana mereka bekerja, bagaimana berhubungan dengan atasan ataupun rekan kerja, bagaimana menyelesaikan masalah, dan banyak lagi yang merupakan wujud budaya yang khas bagi setiap perusahaaan. Seperti halnya "GO SPIRIT" sering dilafalkan dalam kegiatan morning briefing yang dilakukan oleh seluruh karyawan bank BJB dalam upaya menginternalisasikan nilai-nilai budaya dari perusahaan sebagai pedoman.

Fungsi budaya organisasi bagi karyawan menurut Ismail, (2017), antara lain (1) memberikan arahan atau pedoman berperilaku di dalam perusahaan; (2) agar mempunyai kesamaan langkah dan visi dalam melakukan tugas dan tanggung jawab; (3) masing-masing individu dapat meningkatkan fungsinya dan mengembangkan tingkat interdependensi antar individu atau bagian yang lain saling melengkapi dalam kegiatan perusahaan; (4) mendorong mencapai prestasi kerja atau produktivitas yang lebih baik; (5) untuk mencapai secara pasti tentang kariernya di perusahaan sehingga mendorong mereka untuk konsisten dengan tugas dan tanggung jawab masing- masing.

Budaya dalam perusahaan selalu dinamis menyesuaikan dengan tuntutan lingkungan. Dalam menghadapi tuntutan lingkungan, pelaku budaya perusahaan menghadapi berbagai tantangan. Tantangan budaya di sini adalah tantangan yang akan dihadapi oleh pelaku budaya atau suatu lingkungan budaya (sub-budaya, sub-kultur) tatkala berkomunikasi atau berinteraksi dengan pelaku budaya atau lingkungan budaya (sub-budaya) lain. Dengan mengetahui tantangan budaya, pengetahuan tentang bagaimana cara menghadapi dan mengantisipasinya sangat diperlukan, agar tantangan itu berubah menjadi peluang dan kekuatan. Penelitian ini akan difokuskan pada 
bagaimana peran PR dalam menerapkan budaya perusahaan dengan membangun komitmen perusahaan dan karyawan melalui nilai-nilai yang terkandung dalam "GO SPIRIT", serta aktivitas PR dalam menerapkan budaya perusahaan

Komunikasi organisasi merupakan suatu proses dari komunikasi yang terjadi dalam organisasi yang bertujuan untuk menjaga keharmonisan dan kerja sama antara pihakpihak yang memiliki kepentingan. Komunikasi organisasi pada hakikatnya merupakan komunikasi antar manusia yang terjadi dalam lingkungan organisasi. Dengan kata lain, komunikasi organisasi adalah aktivitas pertukaran informasi untuk mengadakan koordinasi antara berbagai sub-sistem dalam suatu sistem organisasi, baik secara formal maupun non-formal. (Suranto, 2018)

Dalam menerapkan budaya perusahaan tentunya komitmen dari para pelaku organisasi sangat dibutuhkan. Konsep komitmen organisasional berkaitan dengan tingkat keterlibatan orang dengan organisasi di mana mereka bekerja dan tertarik untuk tetap tinggal dalam organisasi tersebut. Komitmen dapat diartikan sebagai kesediaan seseorang untuk mengikat diri dan menunjukkan loyalitas pada organisasi karena merasakan dirinya terlibat dalam kegiatan organisasi. Dengan kata lain, komitmen adalah suatu sikap yang mencerminkan loyalitas pekerja pada organisasi. Dengan demikian, budaya perusahaan dan loyalitas kerja berpengaruh terhadap komitmen organisasi dalam menerapkan budaya itu sendiri (Prayudhayanti et al., 2005).

Terdapat tiga tipe komitmen, yaitu affective commitment, keinginan untuk tetap menjadi anggota organisasi karena keterikatan emosional dan keterlibatan dengan organisasi; continuance commitment, keinginan untuk tetap menjadi anggota organisasi karena kepedulian atas biaya yang berkaitan apabila meninggalkannya; serta normative commitment, keinginan untuk tetap menjadi anggota organisasi karena merasa sebagai kewajiban.

Peran PR dalam menerapkan budaya perusahaan tentulah sangat penting, di mana PR diharapkan dapat membangun dan menciptakan komitmen organisasi yaitu rasa memiliki terhadap organisasi, rasa antusias terhadap pekerjaan, dan kepercayaan terhadap manajemen.

\section{Metode Penelitian}

Penelitian ini menggunakan metode kualitatif dengan pendekatan studi kasus sebagai cara untuk mengurai masalah sekaligus menggali informasi yang diperlukan. Studi kasus merupakan salah satu jenis penelitian kualitatif, di mana peneliti melakukan eksplorasi secara mendalam terhadap program, kejadian, proses, aktivitas, terhadap satu orang atau lebih. Studi kasus terikat oleh waktu dan aktivitas dan peneliti melakukan pengumpulan data secara mendetail dengan menggunakan berbagai prosedur pengumpulan data dan dalam waktu yang berkesinambungan (Creswell, 2014).

Informan penelitian harus mampu mewakili dalam memberikan informasi yang selengkap-lengkapnya dan akurat. Adapun subjek penelitian dalam tulisan ini, adalah pimpinan (manajer) dan karyawan dari bank BJB Cabang Singaparna.

Teknik pengumpulan data merupakan langkah yang paling strategis dalam penelitian karena tujuan utama dari penelitian adalah mendapatkan data. Teknik pengumpulan data pada penelitian ini adalah wawancara, observasi, dan studi literatur. Wawancara yang dilakukan oleh peneliti adalah wawancara terstruktur dan semi terstruktur. Selain itu, peneliti juga menggunakan observasi jenis observasi partisipasif, untuk mengetahui dan mengamati bagaimana perilaku karyawan dalam bekerja, bagaimana semangat kerja yang ada, bagaimana hubungan satu karyawan dengan karyawan lain, hubungan karyawan dengan pimpinan, serta bagaimana pimpinan dan 
karyawan mengimplementasikan budaya perusahaan di bank BJB. Sedangkan, untuk studi literatur merupakan teknik pengumpulan data dengan menggunakan buku atau referensi sebagai penunjang penelitian, dengan melengkapi dan mencari data-data yang dibutuhkan dari literatur, referensi, makalah, dan yang lainnya. Peneliti dapat memperoleh data-data atau informasi yang lebih terpercaya dan bisa dipertanggungjawabkan keakuratannya.

\section{Hasil dan Pembahasan}

Budaya perusahaan merupakan hal terpenting yang dibangun dalam bisnis. Terlepas dari ukuran dan status perusahaan, budaya mendorong keterlibatan karyawan dalam memberi motivasi. Budaya perusahaan diaktualisasikan dengan sangat beragam yang dapat berbentuk dedikasi atau loyalitas, tanggung jawab, kerja sama, kedisiplinan, kejujuran, ketekunan, semangat, mutu kerja, keadilan, dan integritas. Semua bentuk aktualisasi budaya tersebut itu bermakna komitmen.

Komitmen organisasi merupakan kesediaan seseorang untuk mengikat diri dan menunjukkan loyalitas pada organisasi karena merasakan dirinya terlibat dalam kegiatan organisasi. Dengan kata lain, komitmen adalah suatu sikap yang mencerminkan loyalitas pekerja pada organisasi dan merupakan suatu proses yang sedang berjalan, di mana peserta organisasi menyatakan perhatian mereka terhadap organisasi dan kelanjutan keberhasilan dan kesejahteraannya.

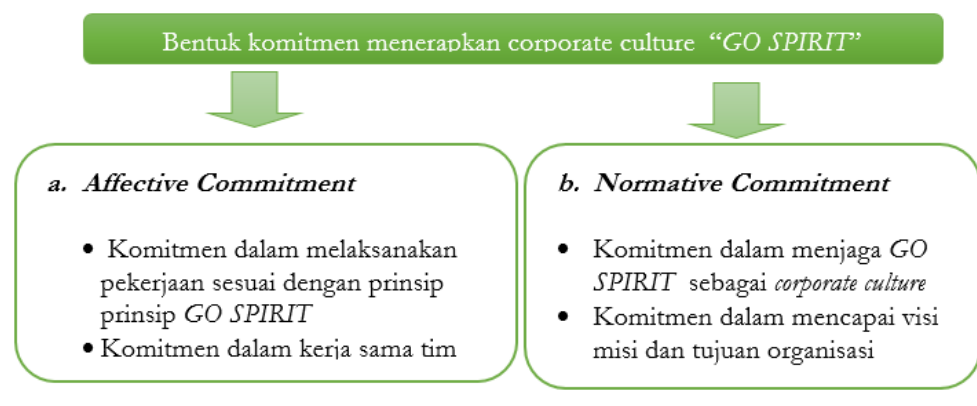

Bagan 1. Bentuk Komitmen Organisasi Sumber : analisa peneliti

\section{Affective Commitment}

Affective Commitment, merupakan suatu keinginan untuk menjadi anggota dari sebuah organisasi karena memiliki keterikatan secara emosional dengan organisasi tersebut. (Ismail, 2017). Pada penelitian ini, affective commitment dalam melaksanakan pekerjaan sesuai dengan prinsip-prinsip "GO SPIRIT". Dalam melaksanakan pekerjaannya, pimpinan dan karyawan senantiasa berpedoman kepada nilai-nilai budaya dari "GO SPIRIT". Pimpinan bank BJB berkomitmen untuk senantiasa menjadi panutan bagi bawahannya dalam mengimplementasikan "GO SPIRIT". Pimpinan tersebut sering memberikan contoh dan arahan kepada bawahannya. Misalnya, saat memberikan semangat dalam mencapai target, manajer itu sendiri memberikan contoh dengan mengajak bawahannya di divisi bisnis untuk membangun relasi dengan calon nasabah maupun nasabah yang sudah loyal, sehingga dengan pendekatan yang seperti itu membuat nasabah menjadi semakin yakin memakai produk BJB.

Sementar itu, manajer operasional memberikan contoh kepada bawahannya langsung, mulai dari tiba di kantor lebih awal, membereskan tata ruang kantor, dan langsung memantau ke meja karyawan. Seperti komitmen dalam kerja sama tim, komitmen ini merupakan komitmen pimpinan dan karyawan bank BJB untuk senantiasa 
mempunyai kerja sama tim yang dapat mempermudah mencapai kinerja perusahaan dan apa yang sudah ditargetkan dalam BJB Prestasiku dapat tercapai dengan baik. Komitmen ini juga untuk menumbuhkan kerja sama tim yang mempunyai rasa solidaritas tinggi sehingga dapat menumbuhkan rasa kekeluargaan dan persahabatan di antara anggota tim.

Affective commitment muncul dan berkembang karena adanya kenyamanan, keamanan, dan manfaat lain yang dirasakan dalam suatu organisasi yang tidak diperoleh dari tempat atau organisasi yang lain. Semakin nyaman dan tinggi manfaat yang dirasakan oleh anggota, semakin tinggi komitmen seseorang pada organisasi yang dipilihnya. Penyebab dari komitmen ini lebih banyak berkaitan dengan pengalaman dan pekerjaan yang dapat memuaskan kebutuhan individu secara psikologis sehingga mereka merasa nyaman dan kompeten dalam menjalankan peran mereka dalam pekerjaan. Dengan demikian, sebagai pemimpin dari suatu perusahaan diharapkan dapat memberikan motivasi pada bawahannya untuk dapat menerapkan budaya perusahaan dalam menjalankan berbagai aktivitasnya di perusahaan (Yolanda, 2015).

\section{Normative Commitment}

Normative commitment, merupakan suatu keinginan untuk menjadi anggota bagian dari sebuah organisasi karena adanya kesadaran akan kewajibannya (Ismail, 2017). Sebagai keinginan untuk tetap menjadi bagian anggota dari suatu perusahaan, maka normative commitment harus dilaksanakan. Komitmen dalam mencapai visi dan misi, serta tujuan perusahaan. Komitmen ini merupakan komitmen yang wajib dimiliki oleh setiap pimpinan dan karyawan bank BJB dalam menjaga eksistensi dan reputasi bank BJB. Komitmen jenis ini merupakan komitmen yang bersifat jangka panjang seperti halnya pimpinan (manajer) divisi bisnis yang mempunyai komitmen dalam mencapai visi dan misi, serta tujuan bank BJB yang dilihat dari prestasi yang sudah diraih oleh perusahaan. Bank BJB saat ini sudah menjadi cabang yang berkinerja baik, kinerja keuangan tercapai, dan laba sesuai dengan target. Selain dari segi target pencapaian bisnis, manajer operasional pun mempunyai komitmen untuk mencapai visi dan misi tujuan perusahaan yaitu berkomitmen untuk senantiasa meningkatkan kepuasan nasabah, sehingga dapat mempertahankan loyalitas nasabah.

Komitmen dalam menjaga "GO SPIRIT" sebagai budaya perusahaan. Komitmen ini penting dan wajib dilakukan oleh seluruh pimpinan dan karyawan bank BJB. Budaya perusahaan "GO SPIRIT" merupakan salah satu identitas yang dimiliki oleh bank BJB, identitas organisasi yang berakar dari budaya dan kepribadian organisasi itu sendiri. Identitas organisasi digambarkan atau mengacu pada perilaku organisasi. Dengan demikian, identitas dibangun secara internal oleh perusahaan untuk menjaga identitas bank BJB, khususnya "GO SPIRIT" sebagai budaya perusahaan. Oleh sebab itu, pimpinan dan karyawan pun harus mempunyai komitmen untuk hal tersebut. Komitmen ini ditunjukkan oleh pimpinan dan karyawan bank BJB dalam hal menjaga identitas dan nama baik perusahaan, yang tidak hanya harus dilakukan ketika sedang berada di dalam perusahaan, tetapi wajib juga dilakukan saat berada di luar perusahaan. Selain bentuk komitmen organisasi, peneliti menemukan data di lapangan mengenai cara bank BJB membangun komitmen dengan karyawan bank BJB.

Terdapat tiga pilar atau dimensi dalam membangun atau menciptakan komitmen. Pertama, rasa memiliki terhadap organisasi. Manajer atau pimpinan menciptakan rasa memiliki dengan memastikan bahwa tenaga kerja itu secara simultan diberi informasi, dilibatkan, dan berbagi dalam kesuksesan. Membangun rasa memiliki merupakan resep utama untuk memperoleh komitmen. Rasa memiliki dapat ditingkatkan dengan membuat 
karyawan merasa terlibat, salah satunya keterlibatan dalam pengambilan keputusan. Setiap kesempatan seharusnya digunakan untuk menciptakan keterlibatan melalui tamasya dan kunjungan terorganisasi. Perusahaan mengakui bahwa mengundang keluarga karyawan untuk mengunjungi pabrik atau tempat kerja memberikan kontribusi yang ampuh. Rasa memiliki terhadap organisasi ditunjukkan dengan pimpinan (manajer) bank BJB memberikan penghargaan di akhir periode penilaian untuk karyawan yang memiliki prestasi, dan menjanjikan sebuah promosi jabatan. Prestasi tersebut dilihat dari Indeks Prestasi Kumulatif (IPK) karyawan bank BJB melalui BJB Prestasiku.

Kedua, rasa antusias terhadap pekerjaan. Pilar kedua komitmen ini berasal dari panggilan terhadap tiga kebutuhan tingkat atas: rasa kebanggaan, kepercayaan, dan tanggung jawab terhadap hasil. Dalam konteks komitmen, rasa bangga tidak berkaitan dengan kekakuan (infleksibilitas) ataupun keengganan mempelajari pengetahuan dan keterampilan baru. Rasa bangga banyak berhubungan dengan kepuasan yang timbul dari hidup sesuai dengan standar pribadi, perhatian terhadap kualitas, menerima tanggung jawab secara pribadi terhadap hasil pekerjaan yang dilakukan, dan kesediaan mendapatkan pelatihan keterampilan baru. Karakteristik penting dari rasa bangga adalah kesadaran perlunya berkontribusi terhadap kinerja standar organisasi yang tinggi. Rasa bangga diyakini sebagai karakteristik pekerja profesional. Ketika diberi tanggung jawab untuk menyelesaikan pekerjaan, pegawai harus memahami secara pasti hal-hal yang harus dicapai dan menerima tanggung jawab untuk melakukan pekerjaan itu. Rasa antusias terhadap pekerjaan ditunjukkan ketika setiap karyawan bank BJB harus mengisi target-targetnya dalam bulanan, triwulanan, semesteran, atau tahunan, yang akan menjadikan parameter pencapaian di saat akhir periode penilaian. Selain itu, rasa antusias untuk mempelajari hal-hal yang baru mengenai pekerjaan di bank BJB, seperti, adanya pelatihan diklat, seminar, dan pelatihan pengembangan sumber daya yang lainnya.

Ketiga, kepercayaan terhadap manajemen. Kepercayaan terhadap kepemimpinan manajemen terdiri atas penggunaan otoritas, dalam pengertian tidak melepaskan wewenangnya kepada perwakilan pekerja, kemauan untuk melakukan disiplin, dan pemeliharaan terhadap standar dan tujuan. Komitmen dibangun dan diciptakan atas kepercayaan terhadap manajemen yang ditunjukkan oleh kompetensi manajeman yang dapat melakukan pekerjaan dengan lebih baik dengan bekerja efektif, efisien, dan bertanggung jawab. Dalam membangun kepercayaan terhadap manajemen, karyawan bank BJB senantiasa bekerja dengan efektif, efisien, dan bertanggung jawab. Hal ini pun temasuk ke dalam bentuk profesional dan integritas karyawan sehingga diperoleh komitmen karyawan terhadap bank BJB.

\section{Aktivitas PR dalam menerapkan budaya perusahaan}

Lembaga keuangan seperti bank bukan sesuatu yang asing lagi pada masa kini. Keberadaan bank sangat memiliki fungsi yang besar di sekitar kehidupan manusia. Jika dahulu bank hanya dikenal bagi pihak-pihak yang ingin menabungkan sebagian uangnya, kini fungsi dan kegiatan operasional perbankan semakin beragam. Secara umum, fungsi utama bank adalah menghimpun dana dari masyarakat dan menyalurkannya kembali kepada masyarakat untuk berbagai tujuan sebagai financial intermediary. Begitu juga dengan peran PR yang tentunya sangat dibutuhkan dalam keberhasilan perusahaan, baik hubungan secara internal maupun eksternal. Secara internal, peran PR dibutuhkan untuk mengelola hubungan secara internal seperti menyosialisasikan budaya perusahaan melalui berbagai aktivitas yang dilakukannya. Dalam penelitian ini, aktivitas PR di bank 
BJB dilakukan dengan menerapkan fungsi-fungsi: agent of trust, agent of development, dan agent of service. (Muchtar, 2016).

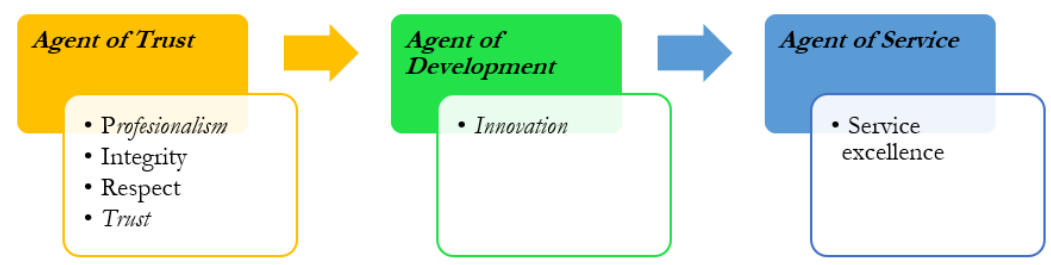

Bagan 2. Bentuk Komitmen Organisasi

Sumber: analisa peneliti

Dalam melaksanakan aktivitas PR, bank BJB tidak terlepas dari nilai-nilai yang telah dianut dan disepakati bersama yaitu "GO SPIRIT" yang terdiri dari enam nilai dan dua belas perilaku. Budaya perusahaan tersebut mencerminkan semangat bank BJB dalam menghadapi persaingan perbankan yang semakin ketat dan dinamis. "GO SPIRIT" sangat berperan dalam aktivitas bank BJB, terutama sebagai pedoman untuk seluruh karyawan bank BJB dalam menjalankan aktivitasnya. Salah satu fungsi dari "GO SPIRIT" yaitu mempunyai kesamaan langkah dan visi karyawan dan pimpinan dalam melakukan tugas dan tanggung jawab. Masing-masing individu dapat meningkatkan fungsinya dan mengembangkan tingkat interdependensi antarindividu atau bagian yang lain saling melengkapi dalam kegiatan perusahaan. Aktivitas PR bank BJB dalam menerapkan "GO SPIRIT" sebagai budaya perusahaan dilakukan dengan agent of trust, agent of development dan agent of service.

Agent of trust. Pada tahap ini aktivitas PR dilakukan dengan cara mengomunikasikan fungsi agent of trust secara internal dan eksternal yaitu kepada top management, pimpinan masing-masing divisi bank BJB, maupun public sehingga timbul rasa saling percaya di antara perusahaan dengan masyarakat. Cara yang dilakukan PR dalam mengimplementasikan agent of trust dilakukan melalui pendekatan komunikasi baik secara langsung maupun melalui media internal perusahaan. Hal ini dilakukan secara intens dan dinamis sehingga apa yang menjadi budaya perusahaan bank BJB mudah dipahami, diimplementasikan, dan dimaknai oleh seluruh stakeholder. Tentunya butuh waktu untuk mencapai budaya perusahaan bank BJB sehingga peran PR sangatlah dibutuhkan.

PR harus melakukan sosialisasi dengan berbagai strategi sehingga budaya perusahaan bisa tertanam di bank BJB. Seperti membangun kepercayaan dan rasa optimis seluruh bagian bank BJB tentang nilai-nilai budaya perusahaan. Misalnya, kepercayaan dari pihak nasabah berkaitan dengan masalah keamanan dana nasabah yang ada di setiap bank. Bank dalam kedudukannya sebagai kreditur, yaitu pihak yang memberikan pinjaman kredit kepada masyarakat atau pihak peminjam dalam menjalankan aktivitas kredit sebagai bisnis intinya, bank harus merasa yakin dan percaya terhadap calon penerima kredit atau debitur. Kepercayaan tersebut meliputi konsistensi dan kejujuran nasabah untuk menggunakan kredit yang diberikan sesuai dengan tujuan permintaan kredit, sehingga tujuan nasabah tercapai dan tujuan bank juga tercapai. Selain itu, aspek kepercayaan itu juga berkaitan dengan kemampuan nasabah untuk membayar kembali pinjaman yang telah diterimanya, baik cicilan bunga maupun pengembalian pokok pinjaman. 
Professionalism. Aktivitas PR ini diterapkan dengan cara menyosialisasikan fungsi dan nilai pada pimpinan dan karyawan bank BJB, salah satunya adalah profesionalisme, yaitu bekerja dengan kompetensi terbaik dan penuh tanggung jawab serta melakukan upaya pengembangan diri secara berkelanjutan. Sikap profesional yang dimiliki karyawan akan berdampak pada kinerja yang baik yang nantinya dapat menjaga identitas dan reputasi bank BJB. Oleh sebab itu, penilaian tidak hanya dari internal tetapi dari eksternal pun menjadi hal yang penting.

Saat professionalism diterapkan, terdapat tiga perilaku utama, yaitu bekerja efektif, efisien, dan bertanggung jawab. Bekerja efektif merupakan sikap bekerja yang bisa memanfaatkan waktu dan biaya, sedangkan efisien adalah dapat memanfaatkan sesuatu yang sudah ada, dan sikap tanggung jawab lahir dari diri sendiri dan ditanamkan mulai dari hal terkecil serta meningkatkan kompetensi untuk menghasilkan kinerja terbaik. Perilaku yang mencerminkan sikap tersebut yaitu mempelajari hal-hal baru untuk mendukung pelaksanaan pekerjaan dan antusias terhadap kesempatan dan tantangan baru, seperti halnya karyawan BJB yang dituntut mempunyai kemampuan yang lebih dari satu. Misalnya, karyawan yang ditempatkan di teller dapat juga bekerja sebagai customer service dan back office.

Integrity. Dalam hal ini, aktivitas PR dilakukan dengan membangun nilai- nilai yang dianut, seperti, konsisten dan komitmen. Nilai-nilai merupakan pegangan dalam bertindak. Integritas ini akan semakin kokoh jika seluruh karyawan dan pimpinan memiliki konsistensi antara apa yang diucapkan dengan apa yang dilakukan (walk the talk) dan memiliki komitmen terhadapnya.

Dalam menerapkan integrity, terdapat tiga perilaku utama yaitu jujur, disiplin, dan konsisten. Setiap karyawan harus mempunyai sikap dan perilaku tersebut. Jujur yaitu menyampaikan hal yang sebenarnya dan menepati janji, menghindari benturan kepentingan, menjaga norma-norma kejujuran, menjaga rahasia perusahaan, serta memahami dan melaksanakan ketentuan yang berlaku. Setiap insan bank BJB diharuskan untuk memahami segala peraturan dan ketentuan yang berlaku. Misalnya, ketentuan dasar atau SOP, SKD direksi, surat edaran, dan lain-lain, serta karyawan bank BJB dituntut untuk menegur atau melaporkan jika terjadi pelanggaran atau ketidakpatuhan.

Respect. Aktivitas PR dalam hal ini yaitu menjalin hubungan yang berlandaskan kepedulian dengan semangat saling menghargai. Dalam menerapkan respect terdapat tiga perilaku utama yaitu menghormati dan menghargai serta terbuka terhadap perbedaan. Setiap karyawan harus menghormati dan menghargai berbagai perbedaan dan tidak membedakan nasabah berdasarkan alasan usia, gender, latar belakang, baik itu, latar belakang pendidikan, latar belakang keluarga, latar belakang suku, latar belakang agama. Karyawan bank BJB harus terbuka dengan tidak membedakan satu sama lain serta harus saling membantu dan ini mencerminkan sikap toleransi terhadap seluruh golongan. Kemudian, memberi dan menerima pendapat yang positif dan konstruktif. Di saat morning briefing, diskusi, dan konseling, harus selalu memberikan saran, masukan perbaikan, harus saling melengkapi, menghormati, dan gotong royong, agar pekerjaan yang berat menjadi ringan. Respect tidak hanya diperuntukkan kepada nasabah saja. Namun respect terhadap karyawan pun sangat dibutuhkan, misalnya ketika ada masalah di perusahaan, dan itu bisa diselesaikan dengan bertukar pikiran dengan pimpinan atau sesama karyawan.

Trust, pada bagian ini PR berusaha untuk menumbuhkan rasa saling percaya, memiliki sangka yang baik dan bersinergi untuk mencapai kinerja terbaik di antara karyawan. Trust memiliki perilaku utama yaitu berperilaku positif. Trust diwujudkan dari image yang dibentuk oleh dari karyawan itu sendiri, baik sedang di dalam kantor atau di 
luar kantor, serta untuk mewujudkan visi, misi, dan tujuan perusahaan seluruh karyawan di berbagai unit divisi. Sikap lain yang mencerminkan perilaku berpikir positif yaitu ceria dan menyenangkan, suportif, dan berani mengakui kesalahan atau menyampaikan kesalahan serta aktif berpartisipasi dalam kegiatan perusahaan.

Kemudian, membangun sinergi untuk mencapai tujuan perusahaan diterapkan dari perilaku seperti bekerja sama dengan unit kerja terkait dalam menyelesaikan masalah, misalnya kerja sama antar divisi, antar cabang, dan dengan kantor wilayah atau kantor pusat. Upaya membangun sinergi karyawan bank BJB yaitu melalui family gathering dengan nasabah. Seperti yang telah dilakukan oleh Bank BJB pada bulan Februari tahun 2019, yaitu melakukan family gathering ke Malaysia. Kemudian employee gathering yang dilaksanakan pada bulan Juli, serta mempunyai komunitas motor milik Bank BJB yang bernama BJB Rider.

Kegiatan-kegiatan PR tersebut dapat menciptakan rasa solidaritas antar karyawan, cabang, bahkan sampai kantor wilayah Bank BJB. Dengan menerapkan nilai Professionalism, Integrity, Respect dan Trust dalam aktivitas perbankan oleh pimpinan dan karyawan dapat menumbuhkan kepercayaan nasabah terhadap perusahaan. Salah satu keberhasilan perusahaan perbankan untuk menjaga eksistensi dan reputasinya yaitu dilihat dari loyalitas nasabah. Oleh sebab itu, sebagai perusahaan yang mengedepankan kepercayaan maka harus disertai keempat nilai tersebut yang merupakan bagian dari budaya perusahaan Bank BJB, yaitu, "GO SPIRIT" sehingga peran PR dalam perusahaan diharapkan dapat mengelola perusahaan secara profesional yang berdampak pada reputasi perusahaan. (Yoga, 2012).

Di samping itu, PR juga membangun kepercayaan secara eksternal dengan pihak luar bank BJB. Dengan calon nasabah baru, PR memberikan motivasi tinggi agar calon nasabah tidak mudah terpengaruh dengan tawaran dari bank lain, sehingga calon nasabah bisa menjadi nasabah yang loyal terhadap Bank BJB. Hal ini perlu terus dilakukan dan dijaga sebaik mungkin agar nasabah merasa nyaman dalam memilih produk-produk yang ada di bank BJB. Sementara membangun kepercayaan dengan pemerintah yaitu mematuhi aturan atau kebijakan perbankan yang dikeluarkan oleh pemerintah.

Agent of development. Pada bagian ini aktivitas PR ditunjukkan sebagai salah satu bentuk tanggung jawab bank dalam menunjang aktivitas transaksi ekonomi perbankan (Muchtar, 2016). Aktivitas PR ini diimplementasikan melalui nilai inovasi oleh seluruh pimpinan dan karyawan Bank BJB sehingga PR selalu memberikan kreativitas dan inovasi baru terhadap produk dan pelayanan Bank BJB. Berbagai produk yang dimiliki oleh Bank BJB merupakan hasil komitmen dari semua stakeholder yang ingin memajukan bank BJB dari berbagai kualitas. Peran PR di sini dilakukan dengan membuat press release dari produk-produk baru bank BJB, melakukan kerja sama dengan berbagai pihak, mematuhi aturan pemerintah tentang aturan perusahaan, misalnya, ada program CSR, charity, kemitraan dan sebagainya dengan harapan bank BJB selalu unggul di mata publik.

Aktivitas PR lainnya dalam agent of development yaitu melakukan penyempurnaan yang berkelanjutan dan menciptakan terobosan baru yang memberikan nilai tambah. Di mana suatu inovasi merupakan ide ataupun gagasan baru yang belum pernah ada ataupun diterbitkan sebelumnya. Sebuah inovasi biasanya berisi terobosan-terobosan baru mengenai sebuah hal yang diteliti oleh inovator (orang yang membuat inovasi). Inovasi biasanya sengaja dibuat oleh inovator melalui berbagai macam aksi ataupun penelitian yang terencana.

Dalam hal ini, aktivitas PR dalam membuat inovasi yaitu adanya perilaku utama yang mencerminkan nilai inovasi dalam bank BJB. Seperti halnya layanan dan bidang operasional, PR mensosialisasikan inovasi tersebut kepada para nasabah sehingga lebih 
memudahkan nasabah dalam melakukan pelayanan. Sehingga dari pelayanan tersebut, nasabah dapat merasa senang, nyaman atas pelayanan yang diberikan bank BJB.

Untuk menunjang fasilitas nasabah, bank BJB melakukan beberapa inovasi di bidang layanan dan teknologi. Bank BJB membangun BJB DigiCash yang dapat mempermudah transaksi nasabah, penambahan ATM di empat tempat baru, adanya aplikasi E-Care dan BJB HC Solution untuk mempermudah keluhan dan saran dari nasabah. Terobosanterobosan ini dilakukan agar bank BJB senantiasa membuat nasabah merasa nyaman untuk melakukan berbagai transaksi dan kepentingan lainnya yang berkaitan dengan bank BJB.

Agent of service. Pada tahap ini, aktivitas PR dilakukan dengan membangun hubungan baik dengan nasabah sehingga bank BJB diharapkan memiliki pelayanan yang lebih unggul dibandingkan dengan bank lainnya. Dalam hal ini, tugas PR adalah menangani secara cepat dan tepat ketika ada keluhan dari nasabah sehingga keluhan nasabah dapat ditampung dan dapat dicari solusinya agar keluhan tersebut tidak berkembang menjadi isu negatif. Di samping itu, PR juga mengadakan pelatihan kepada para staf dengan mengundang pelatih profesional khususnya tentang pelayanan. Hal ini dilakukan dengan harapan bank BJB dapat selalu memberikan layanan terbaik kepada nasabah yang bisa meningkatkan citra perusahaan. Hal ini karena sebagai praktisi PR diharapkan dapat membangun suatu citra yang positif, memelihara citra positif dari suatu perusahaan, meningkatkan citra perusahaan, dan memperbaiki citra apabila terjadi citra yang kurang baik dari suatu perusahaan. (Anggraeni, 2013)

Di bank BJB, agent of service ini dilakukan dengan memberikan pelayanan jasa keuangan sebagaimana kegiatan intermediasi yang dilakukan. Bank juga turut serta dalam memberikan jasa pelayanan yang lain seperti jasa transfer (payment order), jasa kotak pengamanan (safety or box) jasa penagihan atau inkaso (collection), yang saat ini telah mengalami perubahan dengan nama City Clearing.

Secara teori, pelayanan yang prima akan membuat konsumen puas dan memiliki loyalitas dalam memilih bank BJB. Pelayanan prima (service excellence) adalah suatu pelayanan yang terbaik untuk memenuhi harapan dan kebutuhan, memberikan rasa kepuasan, dan menumbuhkan kepercayaan para pelanggan. Dengan kata lain, pelayanan prima adalah suatu aktivitas pelayanan yang berkualitas.

Service excellence merupakan salah satu poin penting dalam keberhasilan dan kelangsungan perusahaan. Sebab, citra perusahaan terbentuk dari penilaian nasabah terhadap bank BJB. Penilaian nasabah meliputi pelayanan dan fitur produk. Berawal dari sambutan nasabah oleh security, sampai pada kebutuhan nasabah yang dipenuhi oleh bagian teller atau customer service. Dalam service excellence terdapat dua perilaku utama. Pertama, fokus pada nasabah, artinya bank BJB harus dapat memenuhi keinginan dan kebutuhan nasabah. Namun sesuai dengan prosedur dan ketentuan yang berlaku, mengerti dan memahami kebutuhan nasabah merupakan hal utama yang harus dilakukan oleh insan bank BJB. Sebagai perusahaan yang mengutamakan standar pelayanan terbaik, insan bank BJB harus dapat mencerminkan sikap peduli terhadap nasabah, kualitas pelayanan terkait dengan upaya pemenuhan kebutuhan dan keinginan pelanggan, serta ketepatan penyampaian harapan pelanggan dengan pelayanan perusahaan.

Kedua, proaktif dan cepat tanggap dalam memberikan layanan bernilai tambah. Layanan perbankan bukan hanya menabung, tapi juga ada fitur produk. Dalam mengimplementasikan "GO SPIRIT" terdapat aksi proaktif dan reaktif. Proaktif adalah ketika bank BJB menyediakan layanan baik itu produk atau jasa. Reaktif adalah bagaimana karyawan bank BJB menanggapi dinamika nasabah. Karyawan bank BJB harus senantiasa cepat tanggap dalam melayani nasabah ataupun menangani keluhan nasabah. 
Dalam rangka memenangkan persaingan, service excellence merupakan modal utama yang menjadi dasar dalam menyusun strategi komunikasi pemasaran dan penjualan jasa. Dengan service excellence, bank BJB menginginkan para nasabah mendapatkan kepuasan. Pada akhirnya service excellence akan menjadi kunci utama dalam usaha industri atau perusahaan mencapai kesuksesan.

Dalam menerapkan service excellence diperlukan komitmen dan keteladanan pimpinan. Artinya service excellence yang sudah direncanakan dan sudah distandarisasi dalam pelaksanaannya harus melibatkan seluruh komponen organisasi, baik jajaran pimpinan maupun karyawan. Selain pelayanan prima, perusahaan memang harus menawarkan sesuatu yang berbeda dan istimewa pada produk, layanan, atau operasional yang dilakukan untuk memuaskan para pelanggan atau segenap stakeholders-nya.

Budaya perusahaan selalu dinamis menyesuaikan dengan tuntutan lingkungan. Dalam menghadapi tuntutan lingkungan, pelaku budaya organisasi menghadapi berbagai tantangan di antaranya tantangan dengan diri sendiri, tantangan dengan nasabah atau mitra, tantangan dengan team building antar divisi yang fungsinya berbeda-beda serta tantangan budaya cabang dan pusat dalam menerapkan "GO SPIRIT".

\section{Tantangan PR dalam menerapkan budaya perusahaan}

Adapun tantangan yang dihadapi PR dalam menerapkan budaya perusahaan, di antaranya bersumber dari nasabah, team building, budaya bank BJB cabang lain, dan tantangan personal. Namun, tantangan tersebut dapat dikendalikan sehingga tantangan tersebut berubah menjadi peluang dan kekuatan.

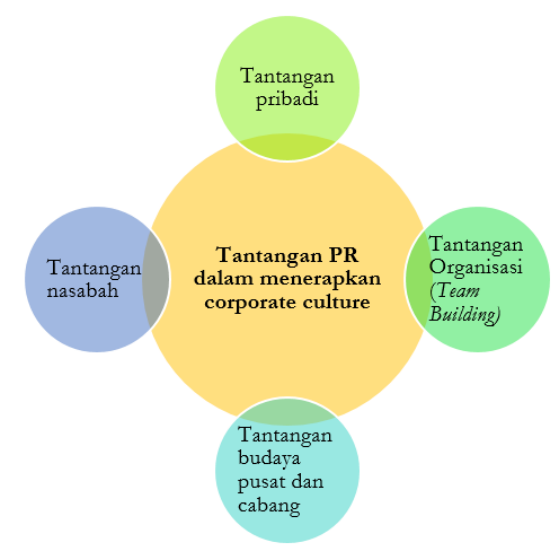

Bagan 3. Tantangan PR dalam Menerapkan budaya perusahaan Sumber: analisa peneliti

Tantangan PR yang pertama berasal dari personal atau budaya pribadi. Tantangan ini menjadi penghambat dalam membentuk semangat tim (team work). Misalnya, setiap karyawan memiliki pemahaman, harapan, dan keinginan yang berbeda sehingga perlu adanya persamaan persepsi dari makna "GO SPIRIT" itu sendiri. Dalam menyatukan kesamaan budaya, visi, misi, dan tujuan organisasi, tantangan terbesar adalah budaya antarpribadi karena budaya ini dipengaruhi oleh latar belakang pribadi yang berbeda. Karena karyawan dan nasabah bank BJB memiliki latar belakang budaya yang berbedabeda, tentunya membutuhkan kesamaan pemahaman dari makna "GO SPIRIT" sehingga pada akhirnya budaya yang tercipta dalam bank BJB merupakan budaya bersama yang bisa dipahami dan diimplementasikan bersama-sama. Meskipun ada karyawan atau nasabah baru yang memiliki budaya yang berbeda, maka adaptasi antar karyawan dengan budaya yang berbeda tidak terlalu menjadi sebuah tantangan dalam menerapkan "GO 
SPIRIT" sehingga dalam membangun sinergi antar karyawan dibutuhkan kesadaran dari pribadi sendiri sebagai bagian dari karyawan bank BJB. Hal ini pun dapat dicerminkan melalui komitmen organisasi dalam kerja sama tim. Dengan demikian, tantangan budaya antar pribadi menjadi salah satu tantangan yang harus diatasi karena perusahaan atau bank BJB sangat bergantung pada individu-individu di dalam suatu perusahaan agar memiliki reputasi yang baik di mata publiknya. (Yoga, 2012)

Selanjutnya, tantangan PR lainnya berasal dari nasabah. Dalam hal ini, ada beberapa stereotip yang berasal dari masyarakat terhadap bank BJB. Misalnya, pelayanan yang kurang memuaskan nasabah. Di sini PR bertindak cepat dengan melakukan klarifikasi terhadap nasabah yang mengalami kualitas pelayanan yang kurang baik dengan menjelaskan kesalahpahaman yang dialami nasabah.

Selain itu, terdapat kecenderungan pembesaran organisasi melalui akuisisi, merger, grouping, dan kemitraan terlebih untuk perusahaan perbankan. Isu dan gosip pun berkembang dalam organisasi. Untuk mengurangi dampaknya dan meningkatkan kepuasan kerja, eksekutif puncak memberikan otonomi mengelola heterogenitas kultur dan mengembangkan subkultur unit kerja level bisnis. Hierarki organisasi diperpendek, hubungan fungsional diperluas, kecerdasan organisasi ditingkatkan, dan desain organisasi diperkecil. Dalam hal ini, tantangan yang dihadapi dalam menerapkan "GO SPIRIT" di masyarakat, bank BJB lebih menekankan pada tantangan untuk nasabah. Selain pihak internal, pihak eksternal seperti nasabah pun menjadi tantangan tersendiri bagi karyawan bank BJB dalam menerapkan "GO SPIRIT".

Selanjutnya, tantangan PR dalam menerapkan budaya organisasi yaitu dari team building. Isu yang berkembang dalam team building ini di antaranya kesenjangan yang terjadi di antara karyawan, baik dari segi finansial, pelayanan pimpinan, karir, dan sebagainya. Posisi PR dalam isu tersebut haruslah objektif, PR dituntut mencari sumber permasalahan, memusyawarahkan secara kekeluargaan dengan pihak terkait dan mencari solusi dari isu tersebut, sehingga hubungan internal bank BJB selalu harmonis. PR juga membuat program-program yang dapat menciptakan kebersamaan dan rasa kekeluargaan di dalam bank BJB. Seperti saat PR memberikan sosialisasi kepada para manager untuk membuat suatu program yang dapat 'menyatukan para karyawan' seperti evaluasi bulanan yang disertai dengan acara makan-makan, atau mengadakan family gathering di cabang bank BJB. Dengan adanya program tersebut, diharapkan dapat menghilangkan kesenjangan yang terjadi di antara karyawan.

Adapun tantangan PR lainnya yaitu, dari adanya perbedaan budaya pusat dan budaya cabang, seperti adanya asumsi yang berbeda antara cabang pusat dan daerah. Walaupun sesama bank BJB, tentunya memiliki implementasi yang berbeda bergantung dari peran PR-nya. Di sinilah tantangan PR untuk menyatukan pemahaman antar bank BJB sehingga budaya perusahaan di setiap bank BJB memiliki makna yang sama.

\section{Simpulan dan Rekomendasi}

Dari pembahasan di atas, maka dapat disimpulkan, peran PR dalam mengimplementasikan budaya perusahaan dilakukan dengan menerapkan nilai-nilai agent of trust, agent of development, dan agent of service. Agent of trust diimplementasikan melalui budaya "GO SPIRIT", yaitu PR melakukan komunikasi dengan membangun fungsi agent of trust secara internal dan eksternal kepada top management, pimpinan masingmasing divisi di bank BJB, hingga publik.

Kedua, agent of development diimplementasikan melalui inovasi oleh seluruh pimpinan dan karyawan bank BJB sehingga PR selalu memberikan kreativitas dan inovasi baru terhadap produk dan pelayanan bank BJB. Ketiga, agent of service, di mana aktivitas 
PR dilakukan dengan membangun hubungan baik dengan nasabah sehingga bank bjb memiliki pelayanan yang lebih unggul dibandingkan dengan bank lainya.

Rekomendasi yang dapat diberikan yaitu dalam menerapkan budaya perusahaan praktisi PR diharapkan dapat membangun komunikasi yang aktif dan interaktif dalam menerapkan komitmen yang lebih baik yang dilandasi dengan kepercayaan di antara internal perusahaan sehingga budaya perusahaan menjadi suatu bagian yang tidak bisa dipisahkan dari aktivitas internal perusahaan. Selain itu, PR juga diharapkan melakukan aktivitas komunikasi yang aktif dan komunikatif agar tumbuh rasa solidaritas yang tinggi antar karyawan, seperti adanya gathering dengan karyawan atau nasabah secara rutin sehingga dapat menjalin hubungan yang harmonis dalam mengatasi permasalahanpermasalahan budaya yang muncul.

\section{Referensi}

Anggraeni, N., Siswoyo, M., \& Nurfalah, F. (2013). Strategi Public Relations dalam Mendukung Pemasaran Pembangkit. Jurnal Mutakalimin Vol.1 Hal. 206-220.

Citra, Anathasia, Yordan Inka, dkk. (2019). Mengkomunikasikan Budaya Kerja $5 S$ (Seiri,Seiso,Seiketsu,Shitsuke,Seiton). EXPOSE - Jurnal Ilmu Komunikasi, Vol. 2. No. 1, Mei 2019 - 170.

Creswell, J.W. (2014). Research Design: Pendekatan Kualitatif, Kuantitatif dan Mixed. Yogyakarta : Pustaka Pelajar.

Ismail. (2017). Corporate culture Kepemimpinan dan Kinerja. Proses Terbentuk, Tumbuh kembang, Dinamika dan Kinerja Organisasi. Depok: Kencana.

Lina, D. (2014). Analisis Pengaruh Kepemimpinan Dan Budaya Organisasi Terhadap Kinerja Pegawai Dengan Sistem Reward Sebagai Variabel Moderating. Jurnal Riset Akuntansi Dan Bisnis, 14, 77-97.

Muchtar, Bustari, dkk. (2016). Bank dan Lembaga Keuangan Lain. Jakarta : Prenada Media Group

Oktaviani, F. (2020). Aktivitas Komunikasi Pubic Relations dalam menjaga Reputasi Perusahaan. Jurnal Signal, 8(1), 15-29.

Prayudhayanti, B. N., Islam, U., \& Agung, S. (2005). Peningkatan perilaku inovatif melalui budaya organisasi. 19-32.

Suranto. (2018). Komunikasi Organisasi. Bandung : PT Remaja Rosdakarya.

Sutrisno, Edy. (2010). Corporate culture. Jakarta : Kencana.

Petra, U. K., \& Siwalankerto, J. (2014). Peran Budaya Organisasi dalam Membangun Employee Relations. Jurnal : Linimasa Vol 2 Hal. 75-84.

Warta, Waska. 2017. Manajemen Reputasi. Bandung : Simbiosa Rekatama Media.

Yolanda, A., Studi, P., Bisnis, A., \& Sawit, K. (2015). Analisis Budaya Organisasi. Jurnal : JIKA Vol. 1 Hal. 34-41.

Yoga, Ahmad (2012). Peran Public Relations dalam Komunikasi Organisasi. Jurnal : LUGAS Vol 1, Hal. 373-380. 